\title{
EFEKTIVITAS TERAPI PNEUMONIA PADA PASIEN PEDIATRIK DI RUMAH SAKIT UMUM PUSAT SANGLAH DENPASAR DITINJAU DARI PARAMETER RESPIRATION RATE
}

\author{
(THE EFFECTIVENESS OF PNEUMONIA TREATMENT IN PEDIATRICS AT SANGLAH \\ HOSPITAL DENPASAR BASED ON RESPIRATION RATE PARAMETERS)
}

\author{
HERLEEYANA MERIYANI ${ }^{\bullet}$, FITRIA MEGAWATI ${ }^{1}$, NI NYOMAN WAHYU UDAYANI ${ }^{1}$ \\ ${ }^{1}$ Akademi Farmasi Saraswati Denpasar, Jalan Kamboja No.11A, Denpasar, Bali
}

\begin{abstract}
Abstrak: Pneumonia merupakan salah satu penyakit yang masih banyak dijumpai pada Negara berkembang seperti Indonesia. Penelitian ini bertujuan untuk mengetahui efektivitas terapi pneumonia pada pasien pediatrik dengan diagnosa pneumonia yang dirawat inap di RSUP Sanglah periode tahun 2014- 2015 ditinjau dari parameter respiration rate (RR) serta melihat pengaruh penggunaan jenis antibiotik (tunggal/kombinasi) dan terapi tambahan terhadap konversi nilai respiration rate (RR). Desain/jenis penelitian ini merupakan penelitian studi cross-sectinal (potong lintang) dengan pengambilan data secara retrospektif terhadap rekam medis pasien. Data yang diperoleh akan dianalisa secara statistika dengan taraf kepercayaan 95\%. Untuk menilai efektivitas terapi pneumonia dilakukan dengan membandingkan Respiration Rate (RR) sebelum dan sesudah terapi. Teknik sampling yang digunakan dalam penelitian ini adalah teknik purposive sampling. Pasien anak degan pneumonia yang menjadi sampel dalam penelitian ini yaitu sebanyak 119 pasien. Berdasarkan analisa statistika Wilcoxon diperoleh bahwa terdapat perbedaan bermakna antara nilai RR sebelum dan sesudah terapi $(\mathrm{p}<0.05)$. berdasarkan analisa statistika Chi-Square diperoleh bahwa jenis antibiotik tunggal maupun kombinasi dan penggunaan bronkodilator tidak berpengaruh terhadap konversi nilai $R R(p>0.05)$, sedangkan penggunaan kortikosteroid berpengaruh terhadap konversi nilai $R R(p<0.05)$.
\end{abstract}

Kata kunci: pediatric, pneumonia, respiration rate.

Abstract: Pneumonia is a disease that is still prevalent in developing countries like Indonesia. The aims of this study were to determine the effectiveness of pneumonia treatment in hospitalized pediatric patients at Sanglah Hospital in the period of 2014- 2015 based on the parameters of respiration rate (RR) and to determine the effect of antibiotics use (single / combined) and an additional therapy towards the conversion of respiration rate (RR). This study was a cross-sectional research study with retrospective data collection based on patient medical records at Sanglah Hospital. The data will be analyzed by a statistical confidence interval level of 95\%. Evaluation of the effectiveness of pneumonia treatment was done by comparing Respiration Rate (RR) before and after therapy. The sampling technique used was purposive sampling technique. Pediatric patients with pneumonia were 119 patients. Based on Wilcoxon statistical analysis the RR before and after treatment was significantly different $(\mathrm{p}<0.05)$. Based on Chi-Square statistical analysis showed that single or combination of antibiotics and use of bronchodilator has no effect on the conversion of RR value ( $p>0.05$ ), while the use of corticosteroids affects the conversion of RR value $(p<0.05)$.

Keywords: pediatrics, pneumonia, respiration rate.

\section{PENDAHULUAN}

Hingga saat ini, infeksi saluran pernafasan pada anak masih merupakan masalah kesehaan yang serius di Indonesia. Pneumonia adalah salah satu infeksi saluran pernafasan yang menyebabkan kematian terbanyak pada balita (Kemenkes, 2012). Di Indonesia pneumonia selalu berada pada daftar 10 penyakit terbesar setiap tahunnya di fasilitas kesehatan. Menurut Survei Demografi Kesehatan Indonesia prevalensi Pneumonia Balita di Indonesia meningkat dari 7,6\% pada tahun 2002 menjadi $11,2 \%$ pada tahun 2007. Pneumonia adalah infeksi parenkim paru yang meliputi alveolus dan jaringan iterstisial, infeksi ini juga disertai inflamasi (Ikatan Dokter Anak Indonesia, 2009). Terapi pneumonia pada pediatrik terdiri atas terapi utama dan terapi tambahan/ penunjang. Terapi utama terdiri atas terapi antibiotik dan terapi tambahan merupakan terapi simtomatis seperti terapi analgetik antipiretik, bronkodilator dan mukolitik. Parameter respiration rate/ RR merupakan salah satu parameter yang dapat digunakan untuk menilai efektivitas terapi

• email korespondensi: ching25.lee@gmail.com 
pneumonia. Untuk mengetahui keberhasilan terapi perlu dilakukan suatu penelitian untuk mengevaluasi efektivitas terapi pneumonia.

Penggunaan obat untuk terapi pneumonia perlu diperhatikan. Pemberian obat yang tidak tepat/efektif akan mengakibatkan hal-hal yang merugikan pasien seperti meningkatkan jumlah bakteri yang resisten, timbulnya peningkatan efek samping dan toksisitas penggunaan obat, terjadinya pemborosan biaya dan tidak tercapainya manfaat klinik optimal dalam pencegahan maupun pengobatan infeksi, sedangkan pemilihan dan penggunaan obat terapi yang tepat/efektif akan menentukan keberhasilan pengobatan serta menghindari hal-hal yang merugikan (Nugroho dkk, 2011).

Dari uraian diatas maka dilakukan penelitian tentang efektivitas terapi pneumonia pada pasien pediatrik dengan diagnosa pneumonia yang dirawat inap di RSUP Sanglah periode tahun 2014 ditinjau dari parameter respiration rate (RR) serta melihat pengaruh penggunaan jenis antibiotik (tunggal/kombinasi) dan terapi tambahan terhadap konversi nilai respiration rate (RR)

\section{BAHAN DAN METODE}

Rancangan Penelitian. Penelitian ini merupakan penelitian cross sectional analitik dengan pengambilan data dilakukan secara retrospektif di RSUP Sanglah Denpasar.

Untuk menilai efektivitas terapi pneumonia akan dilakukan dengan membandingkan nilai respiration rate sebelum dan sesudah terapi. Data yang diperoleh akan di analisis secara statistika dengan taraf kepercayaan $95 \%$.

Bahan. Bahan yang digunakan dalam penelitian ini yaitu catatan rekam medis pasien pediatrik dengan pneumonia di RSUP Sanglah Denpasar.

Metode. Subjek dalam penelitian ini adalah pasien pediatrik dengan pneumonia di RSUP Sanglah Denpasar periode 2014- 2015. Metode pengambilan sampel yang digunakan yaitu purposive sampling. Kriteria inklusi pada penelitian ini yaitu:

1. Pasien pediatrik dengan diagnosa pneumonia berat yang dirawat inap selama tahun 20142015.

2. Pasien pediatrik dengan diagnosa pneumonia berat yang menyelesaikan perawatan hingga dinyatakan boleh pulang oleh dokter.
3. Pasien pediatrik dengan diagnosa pneumonia berat dengan mencantumkan data gejala klinis pasien sebelum dan sesudah dirawat inap.

4. Pasien pediatrik dengan diagnosa pneumonia berat yang mencantumkan nilai neutrofil $>47,1 \%$ (untuk memastikan pneumonia disebabkan oleh infeksi bakteri).

Kriteria eksklusi pada penelitian ini yaitu:

1. Pasien rawat inap pediatrik dengan pneumonia yang dirujuk ke rumah sakit lain.

2. Data rekam medis pasien rawat inap pediatrik dengan pneumonia yang tidak lengkap.

3. Pasien rawat inap balita dengan pneumonia yang meninggal dunia atau pulang paksa.

Parameter yang diamati paa penelitian ini yaitu nilai RR sebelum dan sesudah terapi serta konversi RR. Yang dimaksud dengan konversi RR yaitu perubahan nilai $R R$ dari tidak normal menjadi normal.

\section{HASIL DAN PEMBAHASAN}

Berdasarkan hasil pendataan diperoleh populasi pasien pediatrik dengan diagnosa pneumonia sebesar 452 pasien. Dari 452 pasien sejumlah 119 pasien memenuhi kriteria inklusi.

Tabel 1. Karakteristik Pasien Berdasarkan Jenis Kelamin.

\begin{tabular}{ccc}
\hline Jenis kelamin & Jumlah & Persentase \\
\hline Laki-laki & 71 & $60 \%$ \\
Perempuan & 48 & $40 \%$ \\
Total & 119 & $100 \%$ \\
\hline
\end{tabular}

Ditinjau berdasarkan jenis kelamin, persentase laki-laki sebanyak $60 \%$ sedangkan pasien perempuan sebanyak $40 \%$. Pneumonia lebih sering terjadi pada lak-laki, hal ini terjadi karena diameter saluran pernapasan anak laki-laki lebih kecil dibandingkan dengan anak perempuan serta adanya perbedaan dalam daya tahan tubuh anak laki-laki dan perempuan (Hartati dkk, 2012). Selain itu, secara biologis sistem pertahanan tubuh laki-laki dan perempuan berbeda. Organ paru pada perempuan memiliki daya hambat aliran udara yang lebih rendah dan daya hantar aliran udara yang lebih tinggi sehingga sirkulasi udara dalam rongga pernapasan lebih lancar dan paru terlidung dari infeksi patogen (Kaparang dkk., 2014). 
Tabel 2. Karakteristik Pasien Berdasarkan Usia

\begin{tabular}{lll}
\hline Klasifikasi & Jumlah & Persentase \\
\hline Bayi Baru Lahir (0-1 Bulan) & 8 & 7 \\
Bayi / Infant (1-12 Bulan) & 63 & 53 \\
Toddler (1-3 Tahun) & 38 & 32 \\
Pra Sekolah (3-5 Tahun) & 7 & 6 \\
Usia Sekolah (5-18 Tahun) & 3 & 3 \\
Total & 119 & 100 \\
\hline
\end{tabular}

Apabila dilihat berdasarkan usia, sebanyak 63 pasien $(53 \%)$ merupakan anak berusia 1 bulan sampai 12 bulan. Tingginya kejadian pneumonia yang menyerang rentang umur tersebut, disebabkan oleh imunitas yang belum sempurna karena pada umur tersebut masih mempunyai imunitas pasif yang berasal dari ibunya. Anak dengan sistem imunitas yang tidak sempurna menyebabkan daya tahan tubuh terhadap penyakit infeksi menjadi berkurang, sehingga anak mudah terkena pneumonia (Hapsari, 2007), dan lubang pernapasan yang masih relatif sempit (Hartati, 2012)

Penggunaan terapi antibiotik yang terdapat pada tabel 3, menunjukan bahwa terapi antibiotik yang digunakan terdiri dari terapi antibiotik tunggal dan kombinasi. Pasien yang mendapat terapi antibiotik tunggal terdiri 52 orang dan terapi antibiotik kombinasi sebanyak 67 orang. Terapi antibiotik tunggal yang paling banyak digunakan yaitu Ceftriaxon sebanyak 37 orang (31\%) sedangkan untuk terapi antibiotik kombinasi yang paling banyak digunakan yaitu Ampisilin+ Gentamisin sebanyak 33 orang (28\%), penggunaan terapi antibiotik tersebut merupakan pilihan terapi antibiotik lini pertama yang diberikan jika terdapat pasien anak dengan keluhan pneumonia berat, hal ini sesuai dengan buku tatalaksana pelayanan kesehatan anak di rumah sakit oleh WHO dan Depkes RI.

Tabel 3. Persentase Penggunaan Antibiotik Pasien Pneumonia Balita Rawat Inap RSUP Sanglah

\begin{tabular}{|c|c|c|c|c|c|}
\hline $\begin{array}{c}\text { Penggunaan } \\
\text { Antibiotik }\end{array}$ & $\begin{array}{c}\text { Nama } \\
\text { Antibiotik }\end{array}$ & & $\begin{array}{c}\text { Jumlah } \\
(n=119)\end{array}$ & Persentase & Total \\
\hline \multirow[t]{6}{*}{ Tunggal } & Cefotaxime & & 9 & $8 \%$ & 52 \\
\hline & Ceftriaxone & & 37 & $31 \%$ & \\
\hline & Ceftazidime & & 1 & $1 \%$ & \\
\hline & Cefepime & & 2 & $2 \%$ & \\
\hline & Cefixime & & 1 & $1 \%$ & \\
\hline & $\begin{array}{l}\text { Piperacilin } \\
\text { tazobactam }\end{array}$ & & 2 & $2 \%$ & \\
\hline Kombinasi & $\begin{array}{l}\text { Ampisilin } \\
\text { Gentamisin }\end{array}$ & + & 33 & $28 \%$ & 67 \\
\hline
\end{tabular}

\begin{tabular}{clccc}
\hline \multirow{2}{*}{$\begin{array}{c}\text { Penggunaan } \\
\text { Antibiotik }\end{array}$} & \multicolumn{1}{c}{$\begin{array}{c}\text { Nama } \\
\text { Antibiotik }\end{array}$} & $\begin{array}{c}\text { Jumlah } \\
\text { (n=119) }\end{array}$ & Persentase & Total \\
\cline { 2 - 3 } & $\begin{array}{l}\text { Ampisilin } \\
\text { Kloramfenikol } \\
\text { Cefotaksim }\end{array}$ & 28 & $24 \%$ & \\
& $\begin{array}{l}\text { Azitromisin } \\
\text { Ampisilin } \\
\text { Azitromisin } \\
\text { levofloxacin } \\
\text { cefepime } \\
\text { cefepime } \\
\text { amikasin } \\
\text { cefoperazone+ } \\
\text { sulbactam+ } \\
\text { amikacin }\end{array}$ & 1 & $1 \%$ \\
\hline
\end{tabular}

\section{Gambaran pengobatan terapi pneumonia.}

Penggunaan terapi obat tambahan, dapat dilihat pada tabel 4 , yang menunjukan terapi obat tambahan yang digunakan terdapat 4 golongan, meliputi: golongan antipiretik (66\%), Ekspektoran (92\%), kortikosteroid (51\%) dan Bronkodilator (50\%). Dari keempat obat terapi tambahan tersebut, diduga pemberian bronkodilator dan kortikosteroid berpengaruh perbaikan terhadap respiration rate $(\mathrm{RR})$.

Untuk melihat efektivitas terapi pneumonia pasien rawat inap balita di RSUP Sanglah ditinjau dari parameter respiration rate (RR) digunakan obat antibiotika dan obat tambahan (bronkodilator dan kortikosteroid). Efektivitas terapi dilihat dengan membandingkan respiration rate $(\mathrm{RR})$ sebelum dan sesudah terapi menggunakan statistika uji alternatif Wilcoxon, karena data tidak terdistribusi normal. Uji Wilcoxon dapat dilihat pada tabel 5, hasil uji statistik menunjukan bahwa terapi pneumonia secara umum mempengaruhi penurunan respiration rate $(\mathrm{RR})$ dengan nilai $\mathrm{p}=0,001$ sehingga terapi pneumonia secara umum jika dilihat dari penurunan respiration rate (RR) pada pasien rawat inap balita di RSUP Sanglah sudah efektif.

Tabel 4. Persentase Penggunaan Obat Tambahan Pasien Pneumonia Balita Rawat Inap RSUP Sanglah

\begin{tabular}{|c|c|c|c|c|}
\hline \multirow[t]{2}{*}{ No. } & \multirow{2}{*}{$\begin{array}{c}\text { Golongan } \\
\text { Obat }\end{array}$} & \multirow[t]{2}{*}{ Nama Obat } & \multirow[t]{2}{*}{ Jumlah } & $\begin{array}{c}\text { Persentase } \\
(\%) \\
\end{array}$ \\
\hline & & & & $n=119$ \\
\hline 1 & Antipiretik & Parasetamol & 78 & $66 \%$ \\
\hline 2 & Ekspektoran & Ambroksol & 110 & $92 \%$ \\
\hline & & Deksametason & 56 & $47 \%$ \\
\hline 3 & Kortikosteroid & $\begin{array}{l}\text { Metil } \\
\text { Prednisolon }\end{array}$ & 5 & $4 \%$ \\
\hline 4 & Bronkodilator & Salbutamol & 60 & $50 \%$ \\
\hline
\end{tabular}


Tabel 5. Evaluasi Terapi Pneumonia Dilihat Dari Respiration Rate (RR) sebelum dan sesudah terapi

\begin{tabular}{lccc}
\hline Respiration Rate $(\boldsymbol{R R})$ & N & $\begin{array}{c}\text { Rerata } \pm \\
\text { S.b }\end{array}$ & P \\
\hline Sebelum & 119 & $49,41 \pm$ & 0,001 \\
& & 10,790 & \\
Sesudah & 119 & $31,22 \pm$ & \\
& & 5,152 & \\
\hline
\end{tabular}

Untuk melihat pengaruh penggunaan terapi antibiotik atau terapi tambahan (bronkodilator dan kortikosteroid) terhadap perubahan nilai respiration rate (RR), dianalisis lebih lanjut menggunakan uji chi-square yang ditunjukan pada tabel 6,7 dan 8. Berdasarkan hasil uji chi-square dilihat pada tabel 6 .

Tabel 6. Pengaruh Pemberian Antibiotik Terhadap Penurunan Respiration Rate (RR)

\begin{tabular}{cccc}
\hline & \multicolumn{2}{c}{$\begin{array}{c}\text { Respiration } \text { Rate } \\
\text { (RR) }\end{array}$} & \multirow{2}{*}{$\mathbf{P}$} \\
\cline { 2 - 3 } Antibiotik & Konversi & $\begin{array}{c}\text { Tidak } \\
\text { Konversi }\end{array}$ & \\
\hline Tunggal & 39 & 11 & 0,608 \\
Kombinasi & 51 & 18 & \\
\hline
\end{tabular}

Tabel 7. Pengaruh Pemberian Kortikosteroid Terhadap Penurunan Respiration Rate (RR)

\begin{tabular}{lccc}
\hline \multirow{2}{*}{$\begin{array}{c}\text { Pemberian } \\
\text { kortikosteroid }\end{array}$} & \multicolumn{2}{c}{$\begin{array}{c}\text { Respiration Rate } \\
\text { (RR) }\end{array}$} & P \\
\cline { 2 - 3 } & konversi & $\begin{array}{c}\text { Tidak } \\
\text { Konversi }\end{array}$ & \\
\hline $\begin{array}{l}\text { Dengan } \\
\text { Kortikosteroid }\end{array}$ & 52 & 9 & \\
$\begin{array}{l}\text { Tanpa } \\
\text { Kortikosteroid }\end{array}$ & 38 & 20 & 0,012 \\
\hline
\end{tabular}

Tabel 8. Pengaruh Pemberian Bronkodilator Terhadap Penurunan Respiration Rate (RR)

\begin{tabular}{lccc}
\hline \multirow{2}{*}{$\begin{array}{c}\text { Pemberian } \\
\text { bronkodilator }\end{array}$} & \multicolumn{2}{c}{$\begin{array}{c}\text { Respiration Rate } \\
\text { (RR) }\end{array}$} & \multirow{2}{*}{ P } \\
\cline { 2 - 3 } & konversi & $\begin{array}{c}\text { Tidak } \\
\text { Konversi }\end{array}$ & \\
\hline $\begin{array}{l}\text { Dengan } \\
\text { Bronkodilator }\end{array}$ & 46 & 14 & \\
$\begin{array}{l}\text { Tanpa } \\
\text { Bronkodilator }\end{array}$ & 44 & 15 & 0,791 \\
\hline
\end{tabular}

Antibiotika yang digunakan dalam terapi pneumonia ada tunggal dan kombinasi. Hasil juga menunjukan bahwa penggunaan terapi antibiotik tunggal maupun kombinasi tidak berbeda bermakna terhadap konversi nilai respiration rate (RR) $(\mathrm{p}=0,608)$. Hal tersebut disebabkan karena pasien yang menggunakan terapi antibiotik tunggal maupun kombinasi jumlahnya tidak sama, selain itu jenis antibiotik yang digunakan baik tunggal maupun kombinasi beragam, sehingga sulit untuk melihat terapi antibiotik mana yang paling berpengaruh terhadap konversi nilai respiration rate $(\mathrm{RR})$.

Berdasarkan hasil analisis pada tabel 7 , penggunaan obat tambahan kortikosteroid berpengaruh terhadap konversi nilai respiration rate $(\mathrm{RR})(\mathrm{p}=0,012)$. Penggunaan kortikosteroid sistemik masih menjadi perdebatan. Adanya infeksi pathogen pada alveolar dapat melepaskan beberapa mediator inflamasi seperti tumour necrosis factor (TNF)- $\alpha$, interleukin (IL) $-1 \beta,-6$ and -8), anti-inflammatory cytokines (IL-10, IL-1 receptor antagonist dan soluble 55-kDa serta 75$\mathrm{kDa}$ TNF receptors. Pelepasan mediator inflamasi ini bertujuan untuk menghambat progresivitas infeksi dan merupakan mekanisme pertahanan tubuh dari pathogen. Akantetapi pelepasan mediator inflamasi juga mengakibatkan migrasi dari sel sel yang berfungsi dalam pertahanan tubuh seperti neutrophil, limfosit dan platelet dari sistem sirkulasike daerah tempat terjadinya infeksi. Kortikosteroid berperan sebagai antiinflamasi dan immunosuppressant melalui beberapa mekanisme yang kompleks. Pemberian kortikosteroid dapat mengurangi inflamasi yang timbul di paru paru selama terjadinya infeksi (Sabila dkk, 2008). Penelitian lain menyatakan bahwa pemberian kortikosteroid pada kasus infeksi respiratorik bawah akut kurang bermanfaat. Berdasarkan studi yang telah dilakukan, penggunaan kortikosteroid oral, intravena maupun inhalasi pada anak tidak terdapat perbedaan antara kelompok perlakuan dan plasebo terhadap saturasi oksigen, respiration rate (RR) dan lamanya rawat inap (Setiawati L, 2005). Penggunaan kortikosteroid pada pasien dengan infeksi juga perlu dipertimbangkan efek sampingnya (Sabila dkk, 2008). Penelitian lain menyatakan bahwa, penggunaan kortikosteroid pada pasien dengan infeksi pneumonia berat tidak disarankan karena dapat meperparah kondisi pasien. Akantetapi pemberian kortikostroid masih diperbolehkan pada pasien infeksni pneumonia berat yang menerima terapi antibiotik (Salluh dkk, 2008). Pada penelitian ini pasien yang menggunakan terapi kortikosteroid juga menerima terapi antibiotik sehingga kortikosteroid masih dapat diberikan tentunya dengan mempertimbangkan kondisi pasien dan efek samping yang mungkin timbul.

Berdasarkan tabel 8, penggunaan obat bronkodilator tidak berpengaruh terhadap konversi respiration rate $(\mathrm{RR})(\mathrm{p}=0,791)$. Selain itu, 
penggunaan bronkodilator juga masih diperdebatkan. Sebagian peneliti berpendapat bahwa peran bronkodilator cukup bermanfaat dan sebagian lagi tidak bermanfaat (Supriyatno, 2006). Penggunaan bronkodilator pada pasien anak dengan pneumonia masih menjadi perdebatan, beberapa studi menunjukkan penggunaan bronkodilator inhlasi lebih disarankan karena efek sampingnya yang rendah, akan tetapi Sebuah studi Randomized Controled trial yang melibatkan 780 anak dengan pneumonia berat, menyatakan penggunaan bronkodilator pada pasien anak dengan pneumonia menyatakan bahwa penggunaan bronkodilator baik oral maupun inhalasi tidak menunjukkan perbedaan yang signifikan dengan kelompok placebo (WHO, 2012).

\section{SIMPULAN}

Dari hasil penelitian yang telah dilakukan, dapat ditarik kesimpulan bahwa:

1. Pemberian terapi pengobatan pneumonia pasien balita rawat inap di RSUP sanglah periode tahun 2014 sudah efektif dilihat dari perbaikan respiration rate (RR) sebelum dan sesudah diterapi.

2. Pemberian antibiotik (tunggal/kombinasi) dan terapi bronkodlator tidak berpengaruh terhadap konversi respiration rate (RR), sedangkan penggunaan terapi tambahan kortikosteroid berpengaruh terhadap konversi RR.

\section{DAFTAR PUSTAKA}

Badan Penelitian dan Pengembangan Kesehatan. 2008, Riset Kesehatan Dasar (Riskesdas) 2007 Laporan Nasional 2007, Jakarta, Departemen Kesehatan Republik Indonesia diakses pada 18 Januari 2015 , <https://www.k4health.org/laporanNasional \%20Riskesdas\%202007.pdf>

Hartati,S., Nurhaeni N., dan Gayatri D., 2012, Faktor Risiko Terjadinya Pneumonia pada Anak Balita, VI (15), 13-20
Nugroho F, Pri Iswari Utami \& Ika Yuniastuti, 2011, Evaluasi Penggunaan Antibiotik pada Penyakit Pneumonia di Rumah Sakit Umum Daerah Purbalingga, VI (8),141-154.

Pudjiadi, A.H., Hegar, B., Handryastuti, S., Idris, N.S., Gandapura, E.P., dan Harmoniati, E.D., 2009, Pedoman Pelayanan Medis Ikatan Dokter Anak Indonesia, Palembang, Ikatan Dokter Anak Indonesia, Indonesia diakses pada 22 Januari 2015, <https://www.scribd.com/doc/230039622/ped oman-pelayanan-medis-idai-jilid-1-pdf>

Sabila, O., C. Agusti dan A. Torres, 2008, Corticosteroids in severe pneumonia, Europe Respiration Journal; 32:259-264

Salluh, O.I.F.,Pedro Póvoa, Márcio Soares,Hugo C Castro-Faria-Neto, Fernando A Bozza dan Patrícia T Bozza, 2008, The role of corticosteroids in severe community-acquired pneumonia: a systematic review, Critical Care Vol. 12 No 3

Setiawati L, S. Retno Asih dan MS Makmuri, 2005, Tatalaksana Bronkiolitis, Surabaya, (online),www.old.pediatrik.com diakses tanggal 15 Januari 2015.

Supriyatno, B., 2006, Infeksi Respiratorik Bawah Akut pada Anak, Sari Pediatri, Vl(8),100-106

World Health Organization \& Depkes RI, 2009, Pelayanan Kesehatan Anak Di Rumah Sakit, Jakarta.

World Health Organization, 2012, Recommendations for management of common childhood conditions Newborn conditions, dysentery, pneumonia, oxygen use and delivery, common causes of fever, severe acute malnutrition and supportive care, WHO: Switzerland 